\title{
当科に抒ける肘関節授動術について
}

\author{
広島大学整形外科 \\ 住田 佳 樹・村上恒 二 \\ 安達長夫・津下健 哉 \\ 広島市立安佐市民病院整形外科 \\ 住 田 忠 幸
}

\section{Arthroplasty of the Elbow Joint}

by

\author{
Y. Sumida, T. Murakami, N. Adachi \\ and $\mathrm{K}$. Tsuge \\ Department of Orthopedic Surgery, Faculty of \\ Medicine, Hiroshima University
}

\section{T. Sumida}

Division of Orthopedic Surgery, Hiroshima City

Asa Hospital, Hiroshima

For the past 18 years, forty-five stiff elbows mainly following trauma were treated with our operative method, in which postero-lateral skin incision is used.

The feature of our method at exposure of the elbow joint is to maintain the continuity of the triceps tendon by wide subperiosteal stripping, so that early commencement of motion is possible postoperatively and also good exploration of the elbow joint can be obtained.

Out of 45 cases, 41 were followed up with a mean of 6 years and 7 months. Average range of motion was 102 degrees, and 90 per cent of these 41 patients were excellent or good according to Kita's criteria.

From this result, our operative method is thought very useful for the arthroplasty of elbow.

\section{はじめに}

时関節に生じた運動制限は日常生活に大きな支障を およぼすため, その機能再建には古くから種々の試み がなされており，最近では人工関節も用いられてい る. 当科では過去 18 年間主として外傷による肘関 節 拘縮に対してほぼ一定の手術法を用いて加療してきた ので, 今回その手術法について述べるとともに, 術後 成績にも検討を加えたので報告する.

\section{手術法}

手術はまず上腕後外側を下降し时頭に至り同部を斜 走して前腕中枢の尺側に終わる全長約 $20 \mathrm{~cm}$ のゆる
やかな J 字形皮切をおく（図 1 - (1)). 次いで皮下組 織を㓦離して尺側におよび，cubital tunnel 内で尺 骨神経を確認し，乙れにテープをかけて保護してお く. 続いて外側筋間中隔より侵入し, 上腕三頭筋を骨 膜下に剝離して末梢に至るが，三頭筋腱の連続性を絶 つ事なく肘頭部でも骨膜下にてれを外側より内側に向 けて剝離しつつ移動し, 関節後面を広く展開する（図 1 -(2), (3)). 以上の後, 橈側々副靶帯を切離して関 節を内反脱臼せしめながら関節前面も剝離するが，場 合によっては内側関節囊も切離して関節を完全に脱臼 露出せしめて 全周にわたる形成術を行なう（図 1 (4)). すなわち, 拘縮の原因と考えられる関節周 囲の 化骨や痽痕組織, また时頭先端や鉤状突起部の骨棘を 

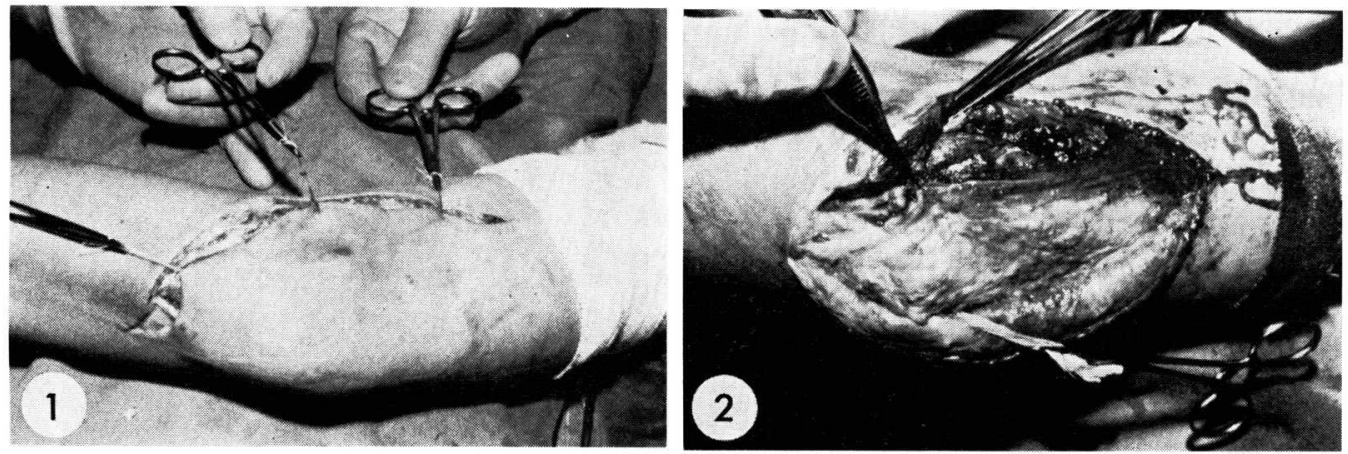

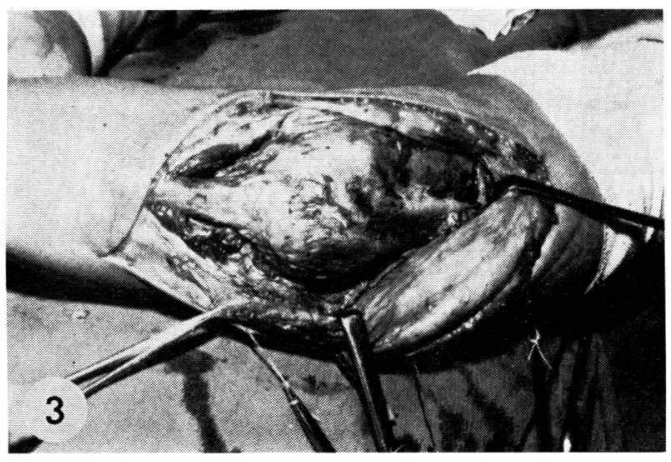

図 1 手

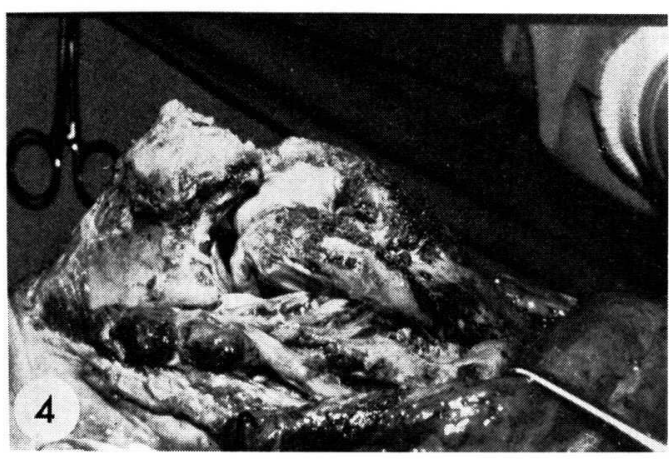

法（左时）

上腕三頭筋腱（写真(2)ピンセットで示す）の連続性を絶つ事なく骨膜下に剝離を進め, 関節を広く展開する

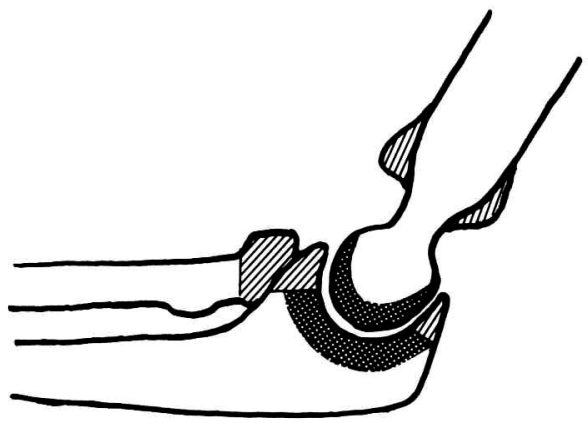

図2 骨切除および化骨切除の範囲

すべて切除する. 橈骨頭も前腕回旋障害とか肘屈曲障 害の原因となっていれば切除する. 更に関節の破壊が 強ければ上腕骨下端, 尺骨関節面の切除を追加して, いわゆる resection arthroplasty を行なっている (図 2 ). また必要に応じて大腿生筋膜を中間指入膜と して用いている.

術後は时直角位でギプス副子固定を行ない, 10 日目 ないし 2 週後より自動運動を開始する.
症例

さて以上の方法で肘関節授動術を行なった症例は過 去 18 年間に 45 例を数える. そのうちわけは男 33 例, 女 12 例, 左右別では右側 30 例, 左側 15 例となり男 性, 右側に多い. 手術時年令は 3 才から 66 才まで, 平均 30 才である. 原因疾患別に分けると顆上骨折, 时頭骨折などの肘関節周辺骨折によるもの 19 例，脱 臼骨折によるもの 14 例, 意識障害あるいは原因 不明 にて関節周囲に化骨を生じたもの 8 例, 変形性関節症 2 例, 化膿性骨髅炎 2 例之なり, 前 2 者の外傷例 が 33 例と多くを占めている.

なお今回の予後調査にあたり成績評価は Kita の基 準 (表 1 ) を用いて, 可動域を中心に関節安定性, 筋 力も含めて判定した.

以下症例を紹介する.

症例 1 : 51 才, 女性. 主婦.

転倒により右上腕骨下端骨折を生じ, 近医で約 1 力 月間ギプス固定をうけた症例で，受傷後 4 力月にて授 動術を行なった. 術前伸展 $-50^{\circ}$, 届曲 $80^{\circ}$ で, 可動 


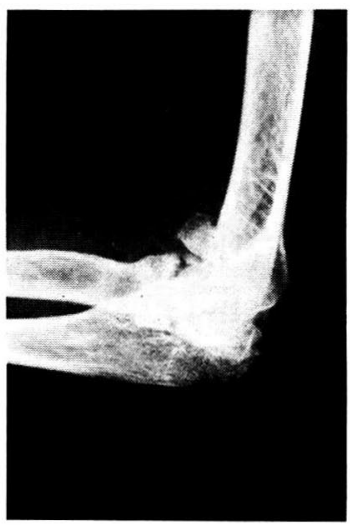

a : 術前のレ線像 (術前可動域 $30^{\circ}$ )

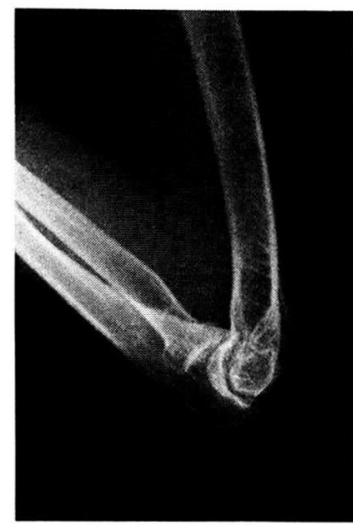

b : 術後のレ線潒 (術後可動域 $115^{\circ}$ )

図3 症例1 51才 女性

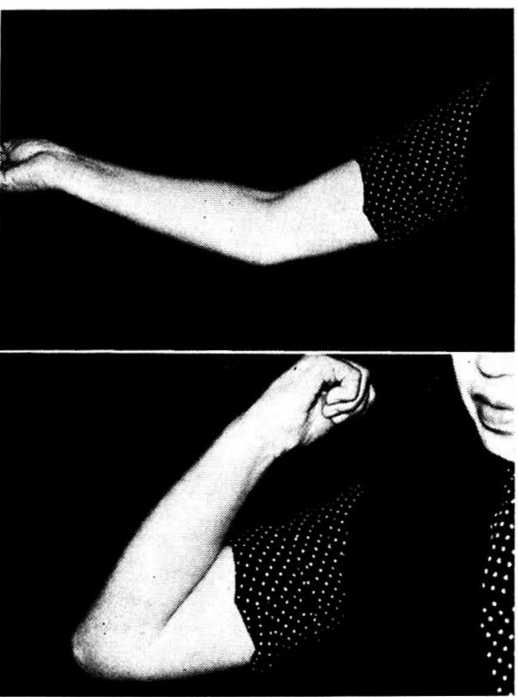

c：術後の屈伸の状態（術後 3 年 8 力月）

\begin{tabular}{c|l}
\hline \hline $\begin{array}{c}\text { Excellent: } \\
\text { (優) }\end{array}$ & $\begin{array}{l}\text { range of motion from 90 to } 120^{\circ}, \\
\text { with good stability and muscle } \\
\text { strength. }\end{array}$ \\
\hline $\begin{array}{c}\text { Good: } \\
\text { (良) }\end{array}$ & $\begin{array}{l}\text { range of motion from 70 to } 90^{\circ}, \\
\text { with satisfactory stability and } \\
\text { sufficient strength for everyday } \\
\text { activities. }\end{array}$ \\
\hline $\begin{array}{c}\text { Fair: } \\
\text { (可) }\end{array}$ & $\begin{array}{l}\text { range of motion from } 40 \text { to } 70^{\circ}, \\
\text { without instability, or adequare } \\
\text { range of motion with instability. }\end{array}$ \\
\hline $\begin{array}{c}\text { Poor: } \\
\text { (不可) }\end{array}$ & $\begin{array}{l}\text { range of motion less than } 40^{\circ}, \\
\text { and/or gross instability. }\end{array}$
\end{tabular}

域は $30^{\circ}$ に制限されており，レ線上関節前方に骨片を 認め, 関節後方には化骨形成もみられる (図 3 a). 術 後 3 年 8 力月の現在, 伸展 $-30^{\circ}$, 屈曲 $145^{\circ}$ で, 可 動域は $115^{\circ}$ と著明に改善しており，成績は優である (図 $3 b, c$ ).

症例 $2: 29$ 才, 男性. 配線工.

遠心分離機に巻きてまれて右肘開放性脱臼骨折を生 ず. 某医にて二回にわたり観血的整復術を受けてい る. 当科受診時, 伸展 $-15^{\circ}$, 届曲 $45^{\circ}$, 可動域 $30^{\circ}$ でレ線上右肘はなお脱臼位にある（図 $4 \mathrm{a}$ ). 受傷後 7 カ月目で resection arthroplasty を施行した. 術 後 9 年目の現在, 伸展 $-20^{\circ}$, 屈曲 $135^{\circ}$ で可動域は

表 2 Kita の基準による成績評価

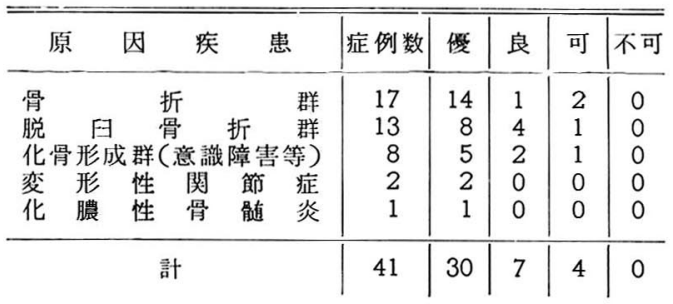

$115^{\circ}$ 之改善している. 軽度の側方動摇性, 前腕回内 障害を残しているが $\mathrm{ADL}$ 上の支障はなく原職にも復 帰している. 成績は優と判定した（図 4 b, c).

症例 $3: 52$ 才, 男性. 無職.

脳卒中で意識障害が 3 力月間続いた後右肘に化骨が 生じた症例で, 術前右肘は $50^{\circ}$ 届曲位にて強直を呈し ていた. レ線上右肘後内側に大きな化骨形成を認める

(図 5 a). 発症後 1 年 8 力月で化骨部切除を主とした 関節授動術を施行した. 術後 4 年 10 力月の現在, 伸展 $-40^{\circ}$, 届曲 $135^{\circ}$ で可動域は $95^{\circ}$ と改善している. 成 績は優と判定した（図 5 b, c).

\section{術 後 成 績}

今回直接検診により予後調查を行ない得た症例は, 手術症例 45 例中 41 例であった. 術後の経過観察期間 は最短 6 力月最長 16 年 4 力月, 平均 6 年 7 力月 であ 


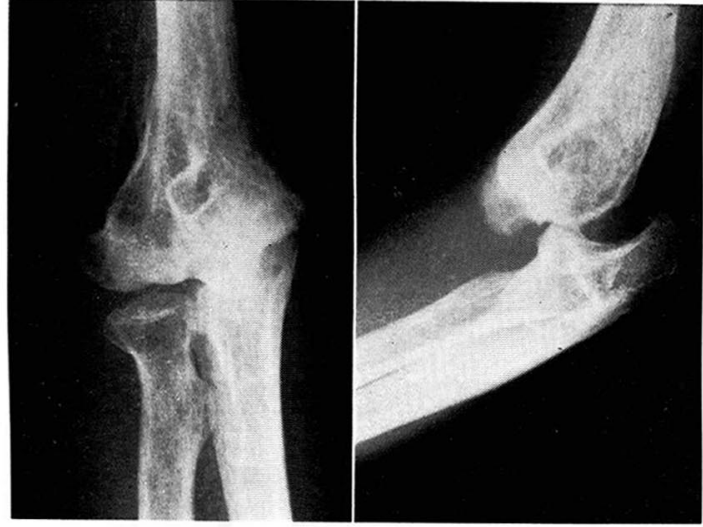

a：術前のレ線像（可動域 $30^{\circ}$ )

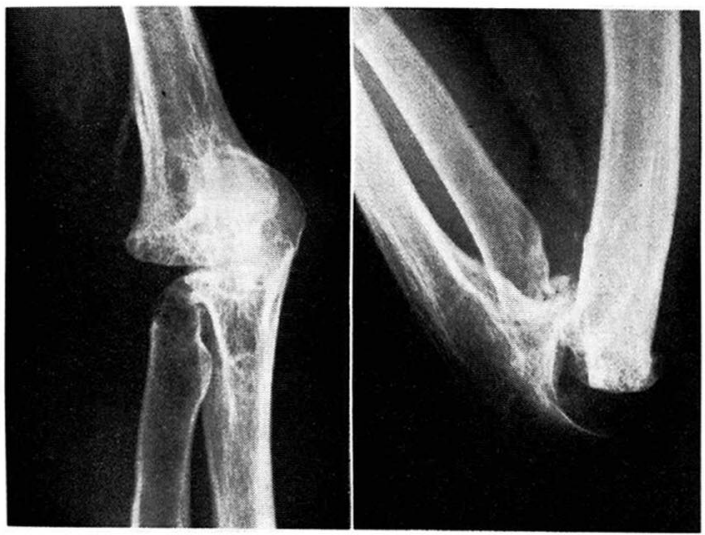

b: 術後のレ線像（可動域 $115^{\circ}$ )

図4 症例2 29 才男性

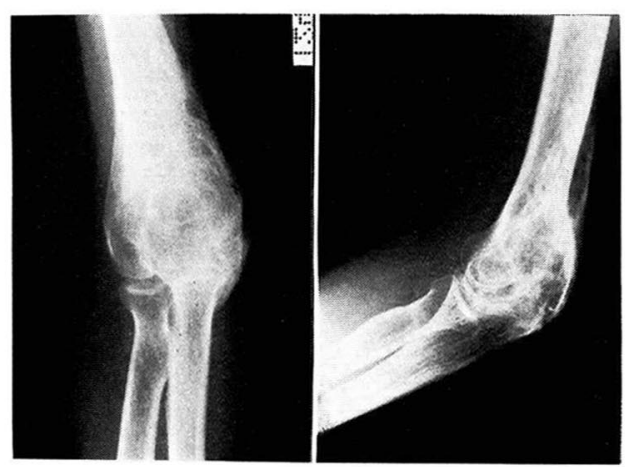

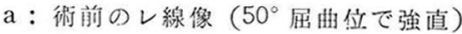

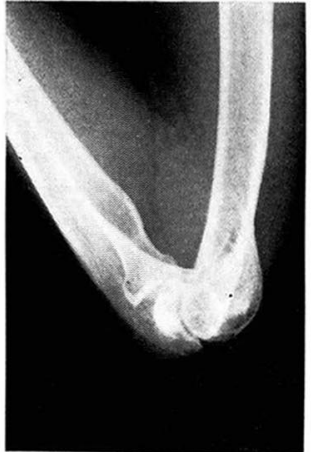

b : 術後のレ線像 （可動域 $95^{\circ}$ )

図 5 症例 3 52才男性
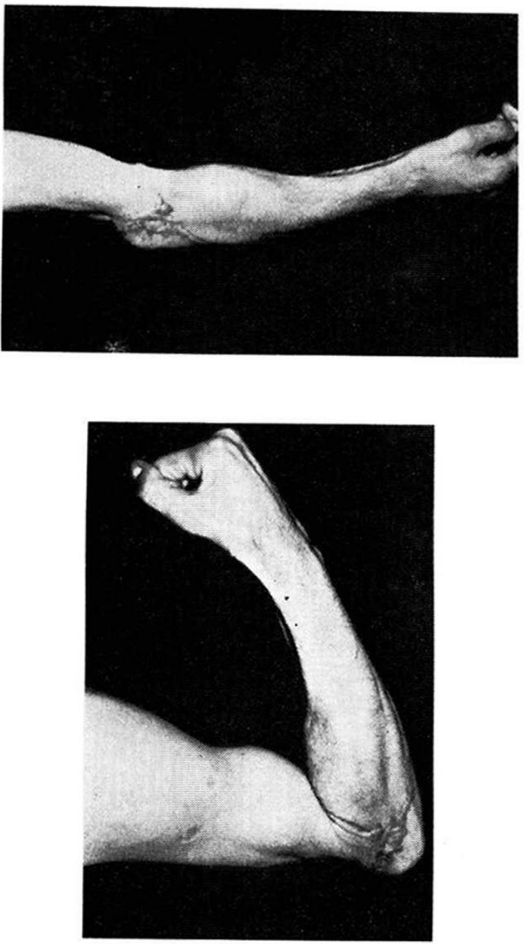

$\mathrm{c} ：$ 術後の屈伸状態（術後 9 年）

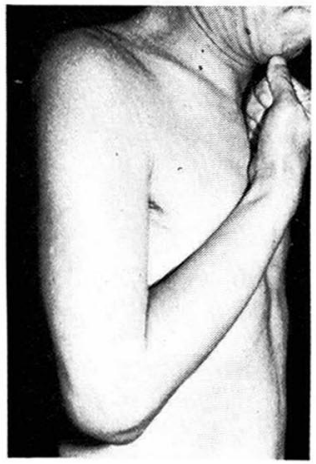

c：術後の屈曲の状態 (術後 4 年10力月) 
る. 以下これら 41 症例の予後調査結果を検討した.

1. Kita の基準による成績評価（表 2)

原因疾患別の評価では, 各グループ間での明らかな 差は認めなかった． 全体としてみると 41 例中，優 30 例良 7 例可 4 例となり，優および良の症例 が 37 例 90 \%を占め良好な結果が得られている.

2. 術前術後の平均可動域（図 6 )

予後調査し得た 41 例の術前後の平均可動域を算出 し図表化した. これによると術前可動域 $38^{\circ}$ が術後は $102^{\circ}$ となり $64^{\circ}$ の改善がみられている. この值は諸 家の報告と比較してもすぐれたあのであった．また図 6 から明らかな様に, 術後は伸展よりも機能上より重 要な屈曲方向への改善度の方が大きく, 術後屆曲角は $127^{\circ}$ となっており ADL 上不自由ないとされる角度 $120^{\circ}$ を十分カバーしている.

3. 原因疾患別の可動域（図 7 )

まず骨折群と脱臼骨折群を比べると, 骨軟部組織の 損傷程度がより強いと考えられる脱臼骨折群の方が術 前術後とも可動域は劣っているが，改善角度としてみ ればいずれも $60^{\circ}$ 前後で大差はない，一方，化骨形成 群は術前可動域 $21^{\circ}$ と最屯劣っているが, 術後は前 2 者の外傷群之同程度の可動域に回復しており改善角度 では $74^{\circ}$ と最もすぐれている.これは化骨群において は外傷による組織損傷が加わってないこと，また関節 軟骨が比較的健常に保たれている例が多いことによる と考えられる.

4. 手術々式別の可動域（図 8 )

Resection arthroplasty を行なった群 8 例と, 主 として化骨や骨棘を切除した群 33 例とに分けて可動 域を比較した. 関節破壊の強い例に行なわれる resection arthroplasty の群の方が術前可動域は当然劣 っているが, 術後可動域では両者の差はあまりなく改 善角度でみるとむしろ resection arthroplasty 群の 方がすぐれている，すなわち関節破壊が強く可動域が 不良なむのに対してあ，十分な骨切除を加えた arthroplasty により良好な可動域を獲得しうると考え られる.

5. 術後可動域の経時的変化（図 9)

てれを角度の記載が明らかなもの 11 例について図 示したあのが図 9 のグラフである. これによると大部 分の症例では, 術後 3 ないし 4 力月までの間に可動域 の急速な改善がみられるが，以後の改善は緩徐でほぼ 術後 1 年で最終的な可動域に落ちつくあのと思われ
る.

6. 外傷群とリウマチ群との比較（表 3)

今回調查した外傷群（骨折群, 脱臼骨折群）之当科 で同様な術式で加療されたリウマチ群との比較を試み た. いずれ す術後 6 年以上経過した長期観察例であ

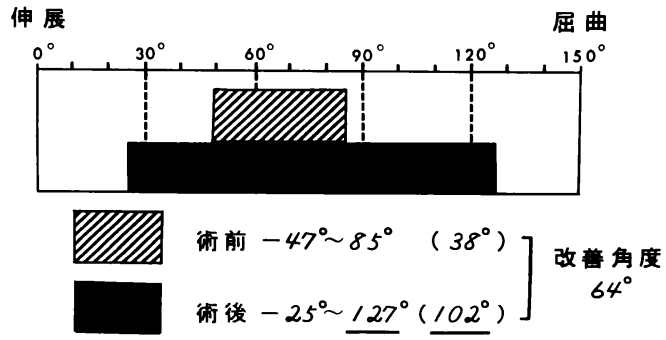

図6術前術後の平均可動域（41例）

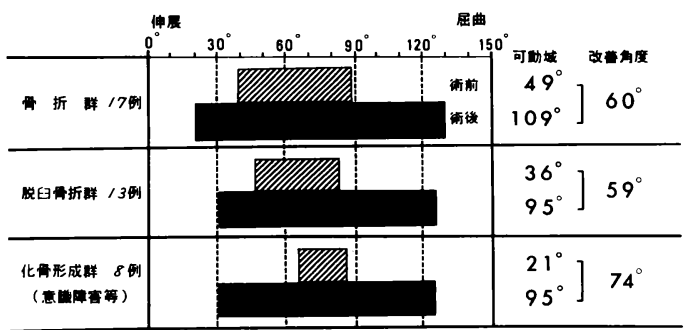

図7原因疾患別の可動域

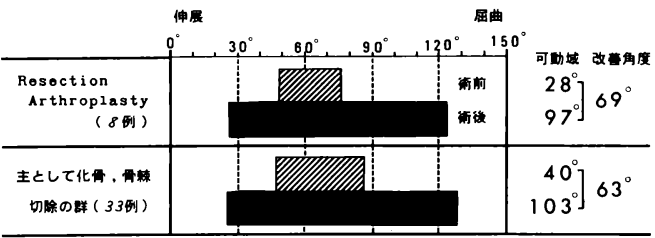

図8手術々式別の可動域

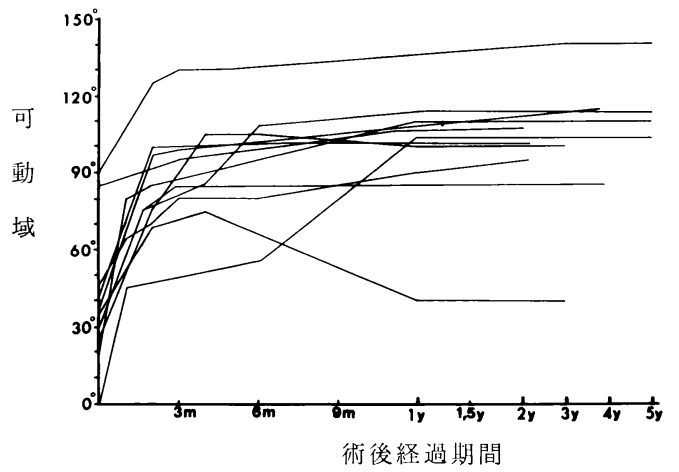

図 9 術後可動域の経㭙的変化 
表 3 外傷群とリウマチ群との比較（遠隔成績）

\begin{tabular}{c|c|c} 
& 外傷 群 & リウマチ群 \\
(6例)
\end{tabular}

る. 術後可動域では外傷群 $102^{\circ}$, リウマチ群 $82^{\circ}$ とな り外傷群の方が明らかにすぐれていた．乙れは外傷群 ではリウマチ群に比べ平均年令が 26 才と若い事, ま た手術までの期間も短く筋力が比較的 保たれている 事，リウマチが進行性の疾患である事などによると考 えられる.

7. 術後の側方動摇性について

Resection arthroplasty を行なった 8 例中 3 例に 側方動摇性を認めた．しかしいずれも内，外方に $20^{\circ}$ 以内で筋力も十分であり不満の訴えはなかった。

\section{考案}

肘関節形成術における侵入法としては，MacAusland，神中らの後方横切開にて时頭を切離する方法 や, Campbell らの後方縌切開にて上腕三頭筋腱を舌 状に切離したり正中縦割する方法などが述べられてい るが，いずれも三頭筋腱の肘頭への連絡を一時的にせ よ絶つものであり，また軟部組織への侵襲が大なる点 からも好ましいものではない．乙れらの欠点を補うべ くわれわれは従来より先に述べた様な三頭筋腱の連続 性を保ったまま肘関節を展開する方法を用いている. 本法は肘関節後方のみならず前面も広くかつ容易に展 開可能で，しかも軟部組織への侵襲も少ないため早期 亿後療法が開始でき術後の筋力低下屯防止できるなよ゙ の利点を有しており，时関節形成術に有用なるのと考 えられる.

今回の予後調査で良好な結果が得られた理由とし て，前述の術式によるとてろが大きいと考えられる が，その他対照症例の術前可動域が平均 $38^{\circ}$ 之諸家の あのより良いとと，外傷例が多くを占め手術までの期 間が平均 2 年 4 力月 と比較的短く筋力の保たれている 症例が多いととなどがあげられる.

次に手術適応についてであるが，われわれは一応肘 関節の屈曲が $90^{\circ}$ 以下に制限され日常生活に著しい支
障をきたしているあのとし，適応をかなり広げてい る.すなわち, 中村らむ述へている様汇洗顔, 食事動 作など ADL 上必須動作の必要角度はいずれも届曲 $110^{\circ} \sim 140^{\circ}$ の間に集中しており，患者の不満の大半は ての屈曲障害にあるといえるからである，従ってかな りの可動域を有していても屈曲が $90^{\circ}$ に満たないあの に対しては，積極的に手術を加え可動域そのあのを拡 大するとともに可動域の $\operatorname{arc}$ をより屈曲側にもって くる様に努力している，そのため最近では, 術後の固 定肢位を $90^{\circ}$ よりやや強めの届曲となし, 術後は伸側 にギプス副子をあてたまま数日目より屈曲運動のみ開 始するように工夫している.

近年，股関節や膝関節に対しては人工関節によるす ぐれた機能再建の成績が述べられているが，てと肘関 節に関しては現在なお異物を用いない関節形成術を慎 重な術式の選択のもとに行なう事により, 長期間安定 した成績が得られるあのと考える.

\section{まと め}

（1）われわれが行なっている时関節授動術の要点を 紹介した.

（2）本術式の成績は，Kita の基準で優良群が $90 \%$ を占め満足すべきものであった.

（3）可動域を中心として種々の見地より術後成績を 比較検討した.

\section{文献}

1) Hurri, L. et al.: Acta Chir. Scand., 127 : 459-465, 1964.

2) Kita, M.: Acta Orthop. Scand., 48: 450455, 1977.

3) Knight, R. A. et al.: J. Bone Joint Surg., 34-A : 610-618, 1952.

4) 河野左宙 ほ 加: 東北整形災害外科紀要, 10: 265-270, 1967

5) MacAusland, W. R. et al. : The New England J. Med., 236: 79-99, 1947.

6) 村上恒二ほか：リウマチ外科, 7:130-136, 1979.

7) 永山五哉ほ加：整形外科，22：1110-1117, 1971.

8）中村信也ほ加：関東整災誌，8：330-334, 1977.

9）津下健哉ほ加：手術, 26：160-166, 1972.

10) Unander-Scharin, L. et al.: Acta Orthop. Scand., 36: 54-61, 1965. 
質 問福岡整形外科病院 小林 晶

(1) 时関節は絶体に屈曲の方が必要であり，乙のた めには上腕三頭筋の延長を行った方がよい.

(2) 外傷性のあのは少なくとも joint débridement のみで良好な成績が得られるようだ。

\section{質 問} 宮崎医大 木村 千似 幼児に対する Arthroplasty は適応にいろいろ問 題があろうと思うが，原因疾患と術後経過についてお たずねしたい.
回答

広島大 住田 佳樹

(1) 3 才の症例は原因不明（点滴？）にて肘拘縮を きたしたもので，軟部組織の release を主として行 なった，術後経過もよい.

(2) 三頭筋の延長を要した症例はない，我々の症例 では外傷例で筋力も十分に得られた例が多いので, 十 分な骨切除により良好な ROM を得られたものと思 われる. 